\title{
Conceptual Symbolic Narration in Virginia Woolf's To The Lighthouse and The Waves from a Reader-response perspective
}

\author{
Said Ahmed Aboudaif \\ Department of English, Faculty of Arts \\ Assiut University, Assiut, Egypt
}

\begin{abstract}
This study examines conceptual, symbolic narration in Virginia Woolf's; To The Lighthouse and The Waves. The study applies the reader-response critical approach to explain the significance of Woolf's metaphoric narration in achieving specific interactions and meanings within her readers' minds. Firstly, it sorts out symbolic language in the two novels to figure out how readers receive them. The analysis shows the heavy use of conceptualized symbolic language to achieve particular meanings and create thematic responses. Secondly, the study clarifies the effect of the conceptual, symbolic narration in revealing the technical aspects in the novels both at the literal meaning and at the symbolic meaning. Thus, the study aims at explaining how the conceptual, symbolic narration plays a functional role in achieving reader-responses to enhance thematic purposes and ideas intended by the writer.
\end{abstract}

Keywords: The Waves, To the Lighthouse, reader-response theory, Virginia Woolf's narration, Virginia Woolf's experimental novels, conceptual narration, symbolic narration

Cite as: Aboudaif, S. A. (2020).Conceptual Symbolic Narration in Virginia Woolf's To The Lighthouse and the Waves from a Reader-response perspective. Arab World English Journal for Translation \& Literary Studies 4 (2) .56 -68.

DOI: http://dx.doi.org/10.24093/awejtls/vol4no2.4 


\section{Introduction}

Virginia Woolf's books and novels represent a turn to modernism. She attracts interest to her exceptional narrative technique. This study explains how she uses conceptual, symbolic narration to achieve specific effects on readers' minds. The study presents a critical analysis of Woolf's To the Lighthouse (1927) and The Waves (1931) to explain her consistent concern with metaphoric language in general and her interest in symbolic narration in particular. Woolf uses excessive symbols in her novels. Consequently, the analysis of her novels aims at explaining that she uses symbolic narration to create emotional reactions and to enhance readers' responses to themes and ideas. She uses conceptualized symbols to create pictures of the whole text to maintain a developed structure while reading the literary text. The critical writings of Woolf reflect her critical points of view, especially her essay 'The Art of Fiction '(1927). Fayzullayeva (2019) confirms:

Still, this kind of achievement is impossible without innovations in the genre of the novel. All aspects of the matter must be considered including writing techniques, main principles in the organization of the novel, and the character's role in the structure of the work. Therefore, it stimulated the next generation and contemporaries' enormous interest in socalled 'experimental novels' (traditionally considered similar to the works like Jacob's Room, Mrs. Dalloway, To the Lighthouse, The Waves, Between the Acts) written by the author where Virginia Woolf gives her theoretical regulations in practice. (p. 212)

Accordingly, this article focuses on the conceptual, symbolic narration to present a critical analysis of the selected texts. It is a method of analysis used by Feuerstein to connect the factual to the fictitious and vice versa. Schapp (1975) defines: “Thomas Feuerstein's works and projects deal with the symbolic manifestations and material of social narratives under the changed circumstances of technology, economy, and politics" (p. 1). Woolf conceptualizes the symbolic language to create catalyst stories transforming dreams of her characters to move from abstract fictional symbols to factual and real-life situations. She uses the direct relationship between the symbol and its signified object. Ward (2003) explains: "Woolf challenges the direct relationship between the symbol and the signified object and also subverts the authority of a symbol to act as a signifier" (p. 1).

\section{Literature Review}

Woolf investigates readers' responses to the nature of fiction. She has her point of view about the role of symbols in the narrative. She tries to define the nature and the real function of symbols in narration. In her critical essay, 'On Not Knowing Greek', she explains; “... a symbol should have some similarity to the thing symbolised, which it should make splendid" (Thakur, 1965, p. 2). She believes that an image can grow to be a symbol to carry the narrative and to create a symbolic narration. "She knew how an image could grow to symbolic potential in order to carry her narrative forward, and she was sensitive to the way poetic connotations accrue to define the numerous inflections upon which the meaning of her novel would rest" (Leaska, 1977, p. 150). She clarifies; "The intuitive realization that a symbol imparts to us should be instant because we start doubting the real and the symbolical if we do not apprehend symbol and meaning simultaneously" (Thakur, 1965, p. 3). Therefore, Woolf asserts: "Symbols should not inform but suggest and evoke"

Arab World English Journal for Translation \& Literary Studies 
(Thakur, 1965, p. 4) which means, that symbols should be left to readers' understanding and interpretation. In short, the symbolic narration is an important element in Woolf's novels.

To The Lighthouse is a landmark of the change from realism to modernism, as Auerbach (1953) mentioned. He explains that the novel employs a new fashion of temporality. It is the gap between the brief time occupied by exterior events and the dreamlike realm of consciousness. Auerbach (1953) explains:

the novel represents a surprising fashion unknown to earlier periods, a sharp contrast results between the brief span of time occupied by the exterior event and the dreamlike wealth of a process of consciousness which traverses a whole subjective universe. These are the characteristic and distinctively new features of the technique..." (p. 538).

Ammar-Guirat (2019) presented a critical analysis of the temporal form of Woolf's To the Lighthouse. He described the narrative structure in terms of break and fissure rather than continuity or unity. The researcher explained that 'the function of Part II 'Time Passes' is one of conveying a ten-year span of oblivion and decay superseding the beauty of human consciousness and its impulse for intersubjective connection exemplified in Mrs. Ramsay" (p. 1). The study provided an extensive analysis of the narrative structure in Woolf's To The Lighthouse.

Besides, Septiyana (2019) described the semantic roles in Lakoff's Owl City song lyrics to find out the types of conceptual metaphors and to analyze the meaning of these metaphors. He concluded that there are conceptual metaphoric expressions used in the lyrics. He added that "the metaphorical expression which the Owl City song lyrics have the difference [sic] meaning in literal. The words, sentences, or clauses which the researchers analyzed as a metaphor in Owl City song lyrics figure something different" (p. 57). So, this study is significant in illuminating the importance of the conceptual metaphorical technique.

Fayzullayeva (2019) offered many details concerning the views of several scientists and authors of many famous literary books of Virginia Woolf and her writing narration experiments. The researcher concluded that many studies show the experimental role in Woolf's technical narration. He added: "Thus the main direction and the line of events become obvious in V. Woolf's experiments carried out on the forms of novels, also, it is seen in the formation and practical implementation of her writing strategy and these things were the most important purposes of this article" (p. 216).

Moreover, Nünning (2017) described an attempt to explore the theory of aesthetics through the analysis of Woolf's essays to illustrate aesthetics in her works. The researcher stated that: "Examining the connections between Woolf's beliefs about aesthetics, it becomes possible to place her thoughts about modernist modes of writing in the context of her overarching framework of ideas concerning literature and literary change" (p. 978). This study elucidated the importance of Woolf as a modernist and the importance of her unconventional narrative technique.

Furthermore, Godfrey (2019) introduced an analysis of the narration in Virginia Woolf's novels. He presented his point of view about her unconventional way of writing and that she is a 
modernist with a unique narrative style. Godfrey (2019) explained that Woof was "writing against literary convention and carefully plotted and contrived novels, she was searching for the way to write human experience without diminishing it with the structure of language" (p. 1). Finally, Li (2019) argued that Woolf uses different elements to present unconventional narration. Li (2019) indicated: "The analysis shows that the heavy repetition of color language concerning scenes has a central function in the depiction of characters' inner world and the revealing of the thematic aspect of a novel both at literal and symbolic levels" (p. 271). Hence, the purpose of this study is to highlight the significance of Woolf's conceptual, symbolic narration and to show the effect of this technique on her readers' responses.

\section{Research methodology}

Critics and readers are interested in the works of Woolf because of her understanding of the change of modern reality. This study analyzes Woolf's To The Lighthouse and The waves using the readerresponse critical approach. This theory focuses on readers and their reactions to a particular literary text. It explains how the reader focuses on the details of a literary text and what are his reactions and responses. It is also related to post-structuralism which, emphasizes the role of the positive reader in receiving the message of a literary text. The experiences of the reader affect the critic's way of tackling the analysis of the text. So, critics take into consideration the freedom and the variety of readers' reactions from different points of view. The modernist critics I. A. Richards, F. R. Leavis, and T. S. Eliot argue that the text is an essential element in the analysis of a literary text. Hence, critics of the reader-response theory use different critical approaches such as Psychological, Feminist, or Structural to interpret readers' reactions. Tyson (2006) explains:

... reader-response theorists share two beliefs: 1) that the role of the reader cannot be omitted from our understanding of literature, and 2) that readers do not passively consume the meaning presented to them by an objective literary text; rather they actively make the meaning they find in literature" (p. 170).

The reader-response critic examines how readers' interactions of a literary text create particular meanings intended by the author. The critic surveys some technical aspects like symbols to find out the effects of these aspects on readers' perceptions. So, the reader-response theory focuses on readers' reactions because they report real meanings and explanations of that literary text. This approach of criticism explains that literature is like art, and readers reflect their specific responses to that art.

\section{To The Lighthouse and The Waves: an Overview}

To The Lighthouse has three parts 'The Window', 'Time Passes', and 'The Lighthouse'. The novel is about Mrs. Ramsay and her family. Her son James, wishes to visit the lighthouse in the future. People around Mrs. Ramsay think that she is beautiful and happy. They concluded that the stocking she is knitting is too short and needs more work. Paul and Minta, who live in the house, are engaged. Lily Briscoe is an unmarried woman with Chinese eyes, and Mrs. Ramsay loves. Mrs. Ramsay is reading poetry, and her husband feels that he wants her to say: "I love you". The reader discovers that Mrs. Ramsay died that night. Children grow, some die, some marry and time passes. Years later, Mr. Ramsay and others return to the summerhouse and decide to go to the lighthouse. 
When Mr. Ramsay and others arrive at the lighthouse by boat, Lily Briscoe at the summerhouse finally finishes her painting with one stroke of a brush.

The waves is Woolf's experimental masterpiece, where the structure of a conventional plot is nearly absent. There are some prose poems in italic to separate the nine chapters of the book. Each prose description is of a set of sea sight where waves are breaking on the shore. There are six characters, three men and three women, who struggle with the death of a beloved friend, Bernard, Louis, Neville, Jinny, Susan, and Rhoda. They speak in monologues that reveal their inner thoughts and life experiences. They express their grief in a chorus soliloquies to find out about the philosophy of both life and death. The narrative voice follows these characters from infancy to maturity with the introductory prose poems to represent the different stages of the characters' lives.

\section{Discussion: Conceptual Symbolic Narration}

The first line of To The Lighthouse is Mrs. Ramsay's promise to James that they will go to the lighthouse: "Yes, of course, if it's fine to-morrow" (Woolf, 1954, p. 1). The narration in the novel is extremely different from the traditional narration of chronological order of events. Therefore, the novelist uses a different technique to connect the events of the novel. Flint (2016) states:

She had already tested readers' expectations about the nature of fiction. In them, as in To the Lighthouse, the centre of consciousness shifts from one character to another, and from their perceptions of the external world at any given moment to their inner life, their associations and memories". (p. 1)

The main characters in the novel are trying to connect and identify their beings. Mrs. Ramsay tries to find meaning in her life and find a balance in giving her husband love and sympathy. She tries to find meaning in his philosophical work to contribute to the progression of thought. Lily Briscoe is considered as an opposite to Mrs. Ramsay. Lily is unable to make a successful relationship. The second part depicts the disconnection of the characters after the death of Mrs. Ramsay. Later, they are joined again through their aspirations. Woolf uses symbols to create a point to involve all the characters in the novel. The Lighthouse is her major symbol. The writer conceptualizes this symbol, which indicates the dream of nearly all the characters in the novel. She presents this symbol on two levels. The physical meaning, the lighthouse (austere, built upon a rock, stark and straight), is standing away at a distance to represent reality to readers who understand that it means a factual reality of life. It also has a mystical meaning to readers as an aspiration, fantasies, and dreams. James wants to go to the lighthouse, but he realizes the separation between his hopes (feeling happy going to the lighthouse) and actual everyday life. James does not expect the lighthouse to be real, and his happiness comes from his desires and dreams. Woolf wants readers to understand that fantasies and realities are separated from each other. The use of the symbol on both levels is to convey a meaning to readers that dreams and fantasies can bring happiness from the dull reality of life. The use of symbols on both sides of factual and fictional is clear in Jessica Johnston's (2014) statement: "Woolf wanted her symbolism to balance carefully on the border between what is apparent and what is obscured, in order to have the desired effect of enhancing the narrative" (p. 24). Woolf (1954) describes:

Arab World English Journal for Translation \& Literary Studies 
Since he belonged, even at the age of six, to that great clan which cannot keep this feeling separate from that but must let future prospects, with their joys and sorrows, cloud what is actually at hand, since to such people even in earliest childhood any turn in a wheel of sensation has the power to crystallize and transfix the moment upon which its gloom or radiance rests, James Ramsay, sitting on the floor cutting out pictures from the illustrated catalogue of the Army and Navy Stores, endowed the picture of a refrigerator as his mother spoke with a heavenly bliss. It was fringed with joy. (p. 3)

Throughout the novel, Woolf uses memories in the order they arise, not in the chronological order of events. This kind of narration is structured around a series of symbols to join the events of the story together. These symbols become motifs connecting the themes in the novel. Apter (1979) illustrates the importance of these symbols; "external objects can become symbols for one's own feelings. As such, they become a means of investigating one's feelings or providing a focus for them" (p. 75). The lighthouse, which stands in water to suggest fluidity and flux, is a conceptualized symbol by the writer to have multiple meanings for readers. It has a spiritual meaning of stable reality that exists and never changes with time. It is also the source of light as it flashes to guide ships. Woolf wants the symbol to guide characters in her novel. The symbol has different meanings to characters. The sense of stability is negative because it means that some people have a stable, boring life, doing the same things over and over again. While other characters are guided by the light to have dreams and goals. The symbol conveys a deeper meaning, as a phallic symbol, related to Mr. and Mrs. Ramsay's relationship, (Water represents the feminine, and the lighthouse represents the masculine). However, Hanna (2012) contradicts this point of view. She states: 'I do not read water as a traditionally 'feminine' symbol, however, because when Mr. Ramsay seeks sympathy from Lily, he himself metaphorically turns to water. Therefore, I think water operates as a symbol of unity - the very thing Mr. Ramsay requires" (p. 40). The lighthouse is just a dream and fancy that brings happiness to James. The response to this symbol is different from one character to another. Woolf confirms: "Nothing is simply one thing" (Woolf, 1954, p. 251). In the novel, Woolf presents an example of James Ramsay cutting a picture of a refrigerator from the Army and Navy Stores catalogue, which is a trivial thing; and cutting it out is a futile activity, passing the time but leading nowhere. She wants to say that sometimes the fantasies cause joy, but lead to nothing in reality. Marsh (1998) states:

Virginia Woolf's significant symbols characteristically express paradoxical ideas in this way. We cannot say 'the lighthouse represents an idealized fantasy' because it is a real lighthouse at the same time as being James's childhood dream. Instead, we can think of the lighthouse as more like a trigger. It provokes us to think about the human tendency to live for a future fantasy, together with all the paradoxical emotions Virginia Woolf conveys as associated with that tendency. (P. 98)

Furthermore, there are many symbols in the novel which Woolf uses to inform readers of the instant meanings needed for narration. The function of these symbols in the narration is to conceptualize her ideas. She uses symbols to enhance ideas and emotions as been explained by Thakur (1965) that the function of symbols in Woolf"s novels, is "to suggest and to give insight into the ineffable in human thought and feeling, or to heighten and make splendid the desired 
emotions and ideas" (p. 4). Woolf beliefs that symbols should be used consciously and intentionally by the writer. In the novel, Woolf uses the symbol of the lighthouse to evoke readers' imagination. Petry (2007) explains how Woolf uses the symbol. He clarifies: "She wants the lighthouse to mean various things to various readers. As there have been so many attempts to interpret the function of the lighthouse in the novel, her idea worked out in a more than satisfying way" (p. 4 ).

Therefore, Woolf relies heavily on symbolic narration to connect the three parts of the novel. We can see how she connects the symbols of both the sea and the waves within Mrs. Ramsay feelings:

She had known happiness, exquisite happiness, intense happiness, and it silvered the rough waves a little more brightly, as daylight faded, and the blue went out of the sea, and it rolled in waves of pure lemon which curved and swelled and broke upon the beach, and the ecstasy burst in her eyes and waves of pure delight raced over the floor of her mind, and she felt, It is enough! It is enough!" (Woolf, 1954, p. 11).

The first part, 'The Window', is full of stories about the Ramsay family and their holiday at the summerhouse, ended around the dinner table. The second part, 'Time Passes', represents the passing of ten years marked by war. The third part, The Lighthouse, is the final part of the morning as if it is the following day of the evening of the first part. The narration in the novel appears as if a cycle of one day, which creates unity in the whole novel. The use of symbols allows the novelist to connect the parts of the novel. This connection is accompanied by the sound of water, which stimulates the thoughts and the feelings of the main characters like Mrs. Ramsay and Lily Briscoe. The use of the water as a symbol means peace of mind and serenity, as well as a connection and unity. In the last part of the novel, when Mr. Ramsay recalls his thoughts and memories about his futile relationship with Mrs. Ramsay. While listening to the sound of water, he soothes himself from the real world to realize the uselessness of his knowledge and intellect. The presence of the sea itself in the novel is a significant symbol that is used by the writer to convey specific meanings to readers. It is a symbol of unification and confirmation of characters beings as mentioned by Hanna (2012):

The sea is a symbol of unification that inspires epiphanies, or 'moments of being' in the characters that disrupt the flow of what Woolf describes as 'non-being', or normal consciousness. Additionally, the physical and spiritual qualities of water illustrate a characters' shift in perspective from that of involvement to that of detachment, and vice versa, and change in their emotional perspective towards one another. Ultimately, the sea and other water images are symbolic of unification that reflects the characters' struggle to find meaning and connection in the world. (P. 35)

Thus, Woolf uses conceptualized symbols of the sea and the water to make the characters realize the crisis of their identities. The characters have dreams to achieve. The symbol of the lighthouse becomes their aim. Likewise, the title of the first part is a conceptualized symbol. The writer presents the image of the window to contradict Lily's image of the sealed hive, which suggests that Lily is blind to an opportunity. However, the writer presents multiple meanings of the window 
as a symbol. The window represents dreams of the future, as well as it represents a deep look at the soul of the character. The symbolic narration at the end of part one explains where Mrs. Ramsay stands on the brink of her husband, who looks at her as she looks out of the window. Woolf (1954) describes: "And as she verified him she began to smile, for though she had not said a word, he knew, actually he knew that she loved him. He could not deny it . . . She had not said it: yet he knew" (pp. 185-86). The use of the window as a conceptualized symbol suggests that people are not sealed to one another. There is a window, one can see through. This is apparent through Mr. Ramsay's knowledge of his wife's love even though she did not say it.

The other significant conceptualized symbol used by Woolf is her understanding of art. Woolf sees art as an organic unity or as a complete whole. The character of Lily Briscoe, the artist who paints all over the novel, expresses her vision of art. Lily wants to connect everything to create s sense of order and unity. Woolf (1954) describes Lily: "She hated playing at painting. A brush, the one dependable thing in a world of strife, ruin, chaos -- that one should not play with" ( p. 170). Woolf highlights the significance of art. It creates unity with life. So, the use of art and life as symbols is to represent wholeness and completeness. Lily and Mrs. Ramsay attempt to use their art and life skills to "compose from ... fragments a perfect whole or read in the littered pieces the clear words of truth" (Woolf, 1954, p. 144). Woolf represents art as a means to create serenity and peace in life when it is full of troubles and problems. Also, the symbol of the brush at the hand of Lily represents the assertion of the of unity between art and life. In the novel, Lily is attached to her brush.

She could not show him what she wished to make of it, could not see it even herself, without a brush in her hand ... becoming once more under the power of that vision which she had seen clearly once and must now grope for among hedges and houses and mothers and children -- her picture" (Woolf, 1954, p. 59).

Woolf presents both life and art as two opposing forces. Both Mrs. Ramsay and Lily find their identities by joining the two forces. The writer describes Lily's understanding of Mrs. Ramsay's silent discourse at the dinner table as:

I am drowning, my dear, in seas of fire. Unless you apply some balm to the anguish of this hour and say something nice to that young man there, life will turn upon the rocks -indeed I hear the grating and the growling at this minute. My nerves are taut as fiddle strings. Another touch and they will snap. (Woolf, 1954, p. 102)

The symbolic narration is conceptualized to represent unity and understanding between the two artists. Lily understands Mrs. Ramsay's desires through the glance in her eyes. Woolf concludes that life needs art to make it immortal. Because life is full of disorder and trouble, it is revealed symbolically as imperfect art. Life and art can create wholeness and unity.

She looked at her picture. That would have been his answer, presumably -- how 'you' and 'I' and 'she' pass and vanish; nothing stays; all changes; but not words, not paint ... One might say, even of this scrawl, not of that actual picture, perhaps, but of what it attempted, that it "remained for ever". (Woolf, 1954, p. 203). 
Woolf in her essay, 'Phases of Fiction', explains her vision of the power of life and art unification. She writes:

It is the gift of style, arrangement, construction, to put us at a distance from the special life and to obliterate its features; while it is the gift of the novel to bring us into close touch with life. The two powers fight if they are brought into combination. The most complete novelist must be the novelist who can balance the two powers so that the one enhances the other. (MacNeille, 1991, p. 101)

Consequently, Woolf uses the two symbols the lighthouse, and the window to make a whole picture around which, revolves the events in the narration. Woolf's ability to create intensive symbolic narration is to convey various meanings and different points of view to readers. She writes about her novel that she aimed at: "Unity, Completeness and Unified whole" (Nicolson \& Banks, 1978, p. 79 ). To The Lighthouse is a novel where Woolf represents the chaos of modernity through her vision of wholeness. She creates conceptual, symbolic narration to intensify ideas to readers and to create a natural cycle to express her points of view.

On the other hand, Woolf uses symbols to join the events in The Waves. The form of the novel is very complex where it shifts from poetry to prose and where the writer uses six soliloquies or voices within the novel. The plot in the novel does not have chronological events, but the writer uses the sea and the waves as two dominant symbols linking the ideas and creating a motif. The sea plays a vital role in referring to different stages of the characters' lives. At the same time, the sea is presented at different stages on the same day from sunrise to sunset. Jinny flows like water. She likes to move and travel. She has a free spirit like water. Woolf (1987) describes Jinny's feelings: "I feel like a thousand capacities spring up in me. I am arch, gay, languid, melancholy by turns. I am rooted, but I flow" (p. 40). So, the connection between the symbol of the sea and the interludes represents the life stages of the characters from infancy to death, where the sunrise represents life and the sunset represents death. The waves are also connected to the lives of the characters, where the tension is represented by the crash of the waves on the seashores. The connection is received by the reader as a natural cycle of unity and solidity. Woolf (1987) describes: "The sun had not yet risen. The sea was indistinguishable from the sky, except that the sea was slightly creased as if a cloth had wrinkles in it" (p. 3). It is explicit that Woolf uses the conceptualized symbolic narration to create an overwhelming feeling of mysticism in this prosepoetic novel.

The natural cycle within the novel moves from the voices to the sea, which means that this natural connection reveals the consciousness of the characters to readers in a mystical atmosphere. Also, Woolf uses conceptualized symbols to present her six characters in a particular way. Each is identified as a symbolic motif: "I see Louis, stone-carved, sculpturesque; Neville, scissor-cutting, exact; Susan with eyes like lumps of crystal; Jinny dancing like a flame, febrile, hot, over dry earth; and Rhoda the nymph of the fountain always wet." (Woolf, 1987, p. 65). The central narration returns to these symbolic identities when those characters struggle at life or losing their pathways. The conceptualized symbols of identity become their life connection and their selfknowledge. Young (1986) explains:

Arab World English Journal for Translation \& Literary Studies 
Of all Woolf's novels, The Waves comes closest to expressing a mythic vision of life. Her interest in the androgynous artist; her attention to "moments of being"; her passion for finding a true self in the flux of time; her use of symbols to express a complex, spiritual vision: these elements in her writing combine to create a mythic vision. (P. 94)

Woolf uses three dominant symbols to convey her meanings and her philosophical points of view: the sea, the waves, and the apple trees. She repeated the symbols in all the chapters, but their meanings are different from one character to another. The sea is a symbol that represents existence and stability. When the characters express their emotions and feelings or narrate their life events, they are surrounded by water.

Woolf's sea symbolism in The Waves is a deliberate aesthetic choice created to give insight into the complex and ineffable in human existence. It is clear from her extensive critical writings on reader response to literary works other than her own that she sought the same results for The Waves. She believed that recurring imagery sunk into the senses to become symbolic. ( Randles, 1985, p. 45)

Water represents life as a flow of time. Also, the sea is a natural force that indicates religious illusion to represent the origin of life. At a spiritual level, water is used for purgation from sins. Woolf conceptualized this symbol to mean the power of change in her characters' minds. So, the water symbol is very suggestive: it has more than one meaning and interpretation. In the narration, Woolf clarifies the significance of water when Percival's death is mentioned:

The waves massed themselves; curved their backs and crashed up spurted stone and shingle. They swept round the rocks and the spray, leaping high, splattered the walls of a cave that had been dry before and left pools inland, where some fish stranded lashed its tails as the wave drew back. (Woolf, 1987, p. 67)

The symbol of the waves is dominant throughout the novel. The sound of the waves represents the natural cycle of life and death, which is endless. The repetition of the sound of the waves comes and goes with the crash on shores, and it is not stable like the thoughts in Rhoda's minds. While it is different in Louis's mind. This fluctuation of the sound is to suggest both unity and change in human personalities. This conceptualized symbols in the novel (water and the waves) have multiple meanings of choice and permanence of life. The fluctuation of the sea represents the characters' change from the chaos of life to the reality of death. Bernard explains his thoughts of change:

I, who had been thinking myself so vast, a temple, a church, a whole universe, unconfined and capable of being everywhere... am now nothing but what you see -- an elderly man, rather heavy, grey above the ears, ... Always it begins again; always there is the enemy, eyes meeting ours; fingers twitching ours; the effort waiting ... Once more, I who had thought myself immune, who had said, 'Now I am rid of all that,' find that the wave has tumbled me over, head over heels, scattering my possessions, leaving me to collect. (Woolf, 1987, p. 208) 
The symbolism is used by the novelist to indicate the dominance of time. It becomes a common feature in the background to all the characters in the novel. It starts with the main characters who are the narrators of the novel as children hearing the sound of the waves. Each one makes his specific meaning and sense of it. Louis hears the stamping of a chained beast. The sound of the waves becomes a sort of rhythm connecting the passing of time. The passing of time connects the relationship between the characters' narration and the sound of the waves. The novel begins with the sound of the waves and ends with the sound of the waves, which represents the continuity of life that is endless. "I note under F, therefore, 'Fin in a Waste of Waters'. I, who am perpetually making notes in the margin of my mind for some final statement, make this mark, waiting for some winter's evening" (Woolf, 1987, p. 107). Also, the rise and fall of the waves indicate the rise and fall in the lives of the main characters. This change represents the drastic change in life, which is not stable but changeable like the waves of a sea.

Woolf uses the symbol of the apple trees unconventionally. The natural sights of the sea, the sky and the apple trees are beautiful scenes but in the novel they are connected to death. "I shall call this stricture, this rigidity, 'death among the apple trees' for ever... But we are doomed, all of us, by the apple trees, by the immitigable tree which we cannot pass" (Woolf, 1987, p. 13). When the main characters heard of the dead man in the gutter, Neville states that people are doomed to death by the apple trees. Li (2011) confirms:

The Waves is a novel exploring death as well as life. It presents the journey of life of the six characters moving from childhood to adulthood, to old age, and to death. In the interludes before each part, there are the descriptions of nature. The changes from the sunrise to the sunset in a day symbolize the different stages in life. (p. 79)

Woolf conveys the meaning that both life and death are combined, as well as sorrow and joy, are combined. Neville was looking at the apple trees when he heard the servants talking about a local murder. So, the symbol becomes related to death. When Neville heard of Percival's death, he feels that he is facing the apple trees which he cannot pass. Woolf(1958) writes: "There was an obstacle. 'I cannot surmount this unintelligible obstacle', I said. And the others passed on. But we are doomed, all of us, by the apple trees, by the immitigable tree which we cannot pass" (p. 12). Woolf conceptualized the beautiful sight of the apple trees to a sinister symbol of death. Moreover, the symbol of the apple tree recalls the biblical story of Adam and Eve as the forbidden fruit. Still, Woolf chooses to deviate the symbol to have a gloomy and sinister feeling all over the novel.

\section{Interpretation}

The conceptual symbolic narration well-matched Woolf's ideas and her modernist experimentation. This technical aspect offers a thematic background for the change of characters' inner feelings. Repetitions of symbols in Woolf's To the Lighthouse and The Waves emphasize the meanings and help the element of characterization and presentation of themes. The mixture of physical symbols and their conceptual meanings helps to highlight the intended motifs of the writer. According to the analysis of the symbols and their significances in the novels, the article explores the effect of this unconventional technique on the readers' responses. Woolf uses symbols to connect the physical to the metaphorical to create unity and wholeness, which add to her 
narrative technique. The symbol of the lighthouse is physical and mystical, just as the death of Percival is a symbol that reflects the inner feelings of the six characters and reflects the idea that death is inevitable to human beings. Woolf's intents that the symbols would have deeper levels of understanding within her readers' consciousness. In To The Lighthouse and The Waves, Woolf used the conceptual, symbolic narration to create harmony and coherence in themes and characterization. The connection between the natural aspects of life and the ideas is obvious throughout the use of symbolism, which adds to readers' feelings and emotions. So, Woolf uses the conceptual, symbolic narrative technique to make it easy to probe into the characters' emotions to deepen the ideas in her novels.

\title{
Conclusion
}

The analysis of the symbolic narration in the selected novels raveled that she had used symbols to add particular metaphorical meanings to her thoughts. She intended to conceptualize these symbols in the narration to add multiple purposes and functions. Nearly all the symbols are conceptualized to signify something different. She realized the significance of conceptualizing her symbols to help readers understand them at once without any delay or ambiguity. The analysis of the symbols illustrates that the conceptual metaphors enhance meanings and ideas in the literary text. This study explains that the reader-response critical approach helps to reveal readers' responses and reactions. Therefore, this article would help readers to have a better understanding of Woolf's symbolic narration and find out more about her experimental novels.

\begin{abstract}
About the Author
Dr. Said Ahmed Aboudaif is a faculty member at the English Department, Assiut University, Egypt. English Literary criticism researcher and writer. I have published some books and articles related to that topic in international Journals and the Amazon site. I am interested in Literature and translation. I have done my studies at home and abroad, where I have done academic studies at the University of Pennsylvania, USA and the University of Iowa, USA.
\end{abstract}

Orcid id: https://orcid.org/0000-0002-4389-9306

\section{References}

Ammar-Guirat, H. (2019). Impersonality Theory as Spatial Imagination in Virginia Woolf's To the Lighthouse. Literary Imagination, 22(1), 42-57. https://doi.org/10.1093/litimag/imz064

Apter, T. A. (1979). Virginia Woolf - A study of Her Novels. London: Macmillan Press.

Buchner, H. (2019). The Function of the Mirror Image in the Perception of the Self in Virginia Woolf's Fiction (Master). Universiteit Leiden

Chlack Randles, B. (1985). The waves of life in Virginia Woolf's The Waves. In A. Tymieniecka (ed.), Poetics of the Elements in the Human Condition: The Sea (pp. 45-56). Dordrecht: Reidel.

Fayzullayeva, U. (2019). Experimental Novels, Written by Virginia Woolf. European Journal of Research and Reflection in Educational Sciences, 7(12), 1-5. 
Flint, K. (2016). An introduction to To the Lighthouse. The British Library. Retrieved from https://www.bl.uk/20th-century-literature/articles/an-introduction-to-to-the-lighthouse.

Godfrey, T. (2019). "The Thing that Exists When We Aren't There": Narration and Mysticism in Virginia Woolf's Novels (Senior English Thesis). Providence College, Digital Commons@Providence.

Hanna, E. (2012). 'I Am Rooted, But I Flow': Virginia Woolf and 20th Century Thought. (Senior Thesis) Retrieved from http://scholarship.claremont.edu/scripps_theses/97

Johnston, J. (2014). Symbolism in Virginia Woolf's Mrs. Dalloway. (BA Thesis). Gothenburg University.

Leaska, M. A. (1977). The Novels of Virginia Woolf: From Beginning to End. London: Weidenfield and Nicolson

Li, Q. (2011). The Absent Presence: A Study of Percival in The Waves. English Language and Literature Studies, 1(1), 77-79. doi: 10.5539/ells.v1n1p77

Li, Q. (2019). Color Language Concerning Scenes in To the Lighthouse. In 2019 2nd International Conference on Arts, Linguistics, Literature and Humanities (ICALLH 2019) (pp. 271-274). UK: Francis Academic Press.

MacNeillie, A. (ed.). (1991). Essays of Virginia Woolf 1919-1924. United Kingdom: Harcourt on Demand.

Marsh, N. (1998). Virginia Woolf. New York: St. Martin's Press; Houndmills: Macmillan.

Nicolson, N., \& Banks, J. (1978). The letters of Virginia Woolf. London: Hogarth.

Nünning, V. (2017). "A Theory of the Art of Writing”: Virginia Woolf's Aesthetics from the Point of View of Her Critical Essays. English Studies, 98(8), 978-994, DOI: 10.1080/0013838X.2016.1241055

Petry, S. (2007). Motifs and Symbols in Virginia Woolf's To the Lighthouse. GRIN Verlag $\mathrm{GmbH}$.

Schapp, W. (1975). Conceptual Narration .Retrieved, from http://www.myzel.net/Narration/vorwort_en.html

Septiyana, A. (2019). An Analysis of Conceptual Metaphor Meaning in Owl City Songs. Counselor: Faizal Risdianto, S.S., M.Hum

Thakur, N. (1965). The Symbolism of Virginia Woolf. London. Oxford University Press

Tyson, L. (2006). Critical Theory Today: A User-friendly Guide (2nd ed.). Hoboken: Routledge.

Ward, J. (2003). Virginia Woolf and her symbols. English-literature-essays.com. Retrieved from https://www.english-literature-essays.com/woolf.htm

Woolf, V. (1954). To The Lighthouse. 1927; reprint, San Diego: Harcourt Brace Jovanovich, HBJ Modern Classic edition.

Woolf, V. (1987). The Waves. New York: Cambridge Press.

Young, D. (1986). The Mythological Element in Virginia Woolf's The Waves: Bernard's Vision. Iowa Journal of Literary Studies, 7(1), 94-104. DOI: 10.17077/0743-2747.1195 